\title{
A Mãe de André de Terrence McNally
}

\author{
Roberto Rillo Bíscaro
}

A peça traduzida a seguir foi originalmente apresentada no dia 18 de maio de 1988, no Manhattan Theater Club - um teatro Off Broadway - na cidade de Nova York. McNally escreveu-a especialmente para um evento chamado Urban Blight, que aconteceu naquela noite. Além deste texto, McNally também contribuiu para o evento com uma outra pequena peça chamada Street Talk. ${ }^{2}$

Em 1990, o autor transformou a peça em um roteiro para televisão, ganhando um prêmio Emmy pela adaptação.

Personagens:

Cal

Arthur

Penny

A mãe de André

Entram quatro pessoas. Elas estão bem vestidas e seguram balões de gás pelos barbantes. As personagens são: Cal, um jovem; Arthur, seu pai; Penny, sua irmã e a mãe de André.

Cal: Sabe o que é realmente horrível? Eu não consigo achar nada especial para dizer. Adeus. Eu te amo. Eu vou sentir sua falta. 
BÍSCARO, Roberto Rillo. A Mãe de André de Terrence McNally

Logo eu que tenho fama de ser tão bom com palavras!

Penny: $\bigcirc$ que é aquilo lá?

Arthur: Pergunte ao seu irmão.

Cal: É um teatro. Um teatro ao ar livre. Eles montam peças lá, no verão. Peças de Shakespeare. (para a mãe de André). Meu Deus, como ele queria fazer Hamlet! Era o maior sonho da vida dele. Acho que ele teria vendido a alma para fazer essa peça. Ele teria ido até Timbuktu para ter outra chance nesse papel. Ele estava tão feliz no verão em que a apresentou em Boston!

Penny: Cal, eu acho que ela não... Agora não é hora. Deixe para mais tarde...

Arthur: Seu filho era... os judeus têm uma palavra para isso...

Penny: (atemorizada). Ai, meu Deus!...

Arthur: Mensch. Eu acho que a palavra é essa. E acho que estou usando-a corretamente. Significa quente, sólido, concreto. Corrija-me se eu estiver errado.

Penny: Legal, pai, legal. Pare enquanto você ainda não falou bobagem!

Arthur: Eu não vou dizer que ele era como um filho para mim. Sabe, nem mesmo o meu filho é sempre como um filho para mim... No fundo, com esse meu jeito meio sem jeito, o que estou tentando dizer é o quanto eu gostava de André. E também o quanto ele me ajudou a conhecer o meu próprio filho. Cal sempre foi meio difícil, mas com André eu podia conversar sobre qualquer assunto. Minha esposa era muito apegada a ele também.

Penny: Eu ainda não entendi o porquê dos balões.

Cal: Eles representam a alma. Quando você o soltar, significa que está deixando a alma dele ir para o Céu. Que você está pronta para deixá-lo partir, cortando o último elo com este mundo.

Penny: $\bigcirc$ Papa sabe disso?

Arthur: Penny! 
Penny: Ora, André adorava meu senso de humor. Escute, dá para ouvir ele rindo. (Ela solta o seu balão branco.) Adeus, seu homem lindo, maravilhoso! Puxa, eu entendo o que Cal quis dizer com relação às palavras... Deus me perdoe por ter desejado que você fosse hetero toda vez que eu olhava para você. Mas se algum homem tinha que ter tido você, fico feliz que esse homem tenha sido meu irmão! Nossa, olha como está subindo rápido! Aposto que isso quer dizer alguma coisa. Alguma coisa ótima...

Arthur: (Arthur solta seu balão.) Adeus. Vá com Deus.

Penny: Cal?

Cal: Eu ainda não estou pronto.

Penny: Tudo bem. Nós vamos estar lá. Vem, pai. Você pode comprar um Good Humor ${ }^{3}$ para a sua filhinha aqui.

Arthur: Eles ainda fabricam Good Humor?

Penny: Fabricam, só que agora o nome é Dove Bars e custam doze dólares. ${ }^{4}$ (Penny sai levando Arthur. Cal e a mãe de Andre permanecem com seus balões.)

Cal: Eu gostaria de saber o que você está pensando. Eu acho que me ajudaria. Você não sabe quase nada sobre mim e eu sei apenas o que André me dizia sobre você. Eu sempre fantasiei que um dia você e eu poderíamos ser amigos. Porém, você não sabia sobre André e eu... Eu me pergunto se você ficaria sabendo, caso isso não tivesse acontecido. Eu me pergunto se algum dia ele contaria para você. Quando ele já estava bem doente eu pedi a ele... Eu pedi a ele mil vezes que contasse para você. "Diz pra ela. Ela é sua mãe! Ela não vai se importar." Mas ele tinha tanto medo de magoar você... E ele também tinha medo da sua reprova. Eu não sei qual dos dois medos era pior. (Nenhuma reação. Ele suspira.) Meu Deus, quantos de nós vivemos nesta cidade porque não queremos magoar nossas mães. Nós vivemos com um medo mortal da reprova de vocês. Nós nos perdemos aqui. Nossas vidas não são furtivas, mas nossos sentimentos com relação a pes- 
soas como você, são! Uma cidade de pessoas que fogem do desprezo de seus pais. De pessoas que não querem magoá-los... Às vezes, quando ele parecia meio para baixo, eu perguntava: "qual o problema, gato?" e um sorriso engraçado, doce e triste aparecia em seu rosto e ele respondia: "Estou com um pouco de saudade de casa, Cal. Só um pouquinho." Eu sempre o acusava de ser um caipira que fingia ser um nova-iorquino sofisticado e descolado. (Suspira.) É uma merda. É tudo uma merda. (Nenhuma reação) Você se lembra do gibi da Luluzinha? A mãe dela não tinha nome. Ela era tão remota e formidável para todas as crianças... Ela era simplesmente a mãe da Luluzinha. Os amigos da menina diziam apenas: "Oi, mãe da Luluzinha." Ela era quase anônima em sua distância. Você me lembra ela. A mãe de André. Deixe-me responder as perguntas que você não tem coragem de fazer e então eu a deixarei em paz e você não terá que me ver nunca mais. André morreu de AIDS. Eu não sei como ele pegou. Eu sou HIV negativo. Ele morreu bravamente. Você teria se orgulhado dele. A única coisa que o amedrontava era você. Eu vou providenciar para que tudo que era dele seja enviado para você. Eu pago. Não são muitas coisas. Você devia ter vindo no verão em que ele fez Hamlet. Ele estava magnífico. Sim, eu estou amargo. Estou amargo porque o perdi. Estou amargo por tudo o que está acontecendo. Mesmo agora, depois de tudo, eu estou amargo porque não consigo me comunicar com você. Eu estou começando a sentir a sua reprova e isto está me deixando enojado. (Ele olha para o seu balão.) Desculpe amigão, eu estraguei tudo. (Solta o balão.) Boa noite, doce Príncipe. E que os anjos venham em coro te embalar o sono. ${ }^{5}$ (derrotado) Adeus, mãe de André. (Sai. A mãe de André permanece sozinha, segurando seu balão branco. Seus lábios tremem. Ela parece à beira de um colapso. Ela está prestes a soltar o balão, mas puxa-o de volta para si. Ela olha para ele um pouco, antes de beijá-lo gentilmente. Solta o balão. Ela o segue com os olhos enquanto ele sobe. As luzes começam a diminuir. Os olhos da mãe de André ainda estão no balão. Blackout.) 


\section{REFERÊNCIAS BIBLIOGRÁFICAS:}

McNALLY, Terrence. Terrence McNally: 15 short plays. Lyme, Smith and Kraus, 1994. p. 347-351.

SHAKESPEARE, William. Hamlet e Macbeth. Trad. Anna Amélia Carneiro de Mendonça e Bárbara Heliodora. Rio de Janeiro, Nova Fronteira, 1995, p. 172.

\section{NOTAS:}

1 Onome original da peça é Andre's Mother.

2 Ambas as peças encontram-se na coletânea Terrence McNally: 15 short plays. Lyme, Smith and Kraus, 1994.

3 Nome de uma marca de sorvete extremamente popular nos anos 50 e 60. Tratava-se de um picolé de creme coberto com chocolate.

4 Dove Bars realmente são idênticas ao sorvete Good Humor e custam muito caro, mas não chegam a 12 dólares. Trata-se de exagero do autor.

5 Decidi adotar a tradução feita por Anna Amélia Carneiro de Mendonça para esta parte de uma fala de Horácio, em Hamlet (Ato V, Cena II). 